The squamosal has an extraordinary development, and extends on the parieto-quadrate arch, and on the inner side of the temporal fossa on each side of the parietal. The parietal is not so far concealed as in Ichthyosaurus, but its posterior lateral process may be seen wedged in between the squamosal and the thin, plate-like opisthotic, which lies external to the supraoccipital on each side. The opisthotic is the parietal of Owen, and the parietal branch of the squamosal is the mastoid of the same author.

This branch in Ichthyosaurus and Lystrosaurus is continuous with the zygomatic portion of the bone, though another element might have been originally coossified with it. The posterior portion of the squamosal is prolonged remarkably; it is applied to the posterior face of the quadratum, and extends to its articular extremity. The quadratum is a small bone of a plate-like form, in contact with the squamosal above and the (?) prootic inwardly and anteriorly. Suprastapedial not distinguished. The parietal branch of the squamosal sends down a columella to the pterygoid. The prootic is a distinct though small bone, below and in front of the squamosal. The presphenoid is plate-like, and much as in the Crocodilia.

Prof. Cope thought that the Anomodontia, one of the earliest (Triassic) types of Reptilia, are one of the best examples of a generalized group among the Vertebrata. Thus the structure of the posterior part of the cranium is largely that of Ichthyopterygia, and partially that of Lacertilia; of the oral parts of the cranium, the prootic and mandible, of Testudinata. The vertebral characters are partly those of Ichthyopterygia, and the sacrum and rib-articulations those of Dinosauria. The peculiar presphenoid is characteristic of Crocodilia, and the osseous interorbital septum of Rhynchocephalia.

The position of the posterior plate of the squamosal in Ichthyopterygia and Anomodontia seemed conclusive as to the homology of that element with the bone covering the cartilaginous quadratum in Batrachia Anura, and the osseous quadratum in Urodela and Dipnoi, called tympanique by Cuvier, and temporo-mastoidean by Dugès. This bone had been already homologized with the præoperculum of Teleostei by Huxley; and it is thought that its present determination in the Reptilia established the serial homology of the præoperculum of the fish with the squamosal plate of the mammal.-Proc. Amer. Phil. Soc. vol. xi. No. 84.

\title{
On the Embryology of Limulus polyphemus.
}

By A. S. PACKARD, Jun.

After a detailed description of the embryological history of the Limulus, the author concludes that before hatching it strikingly resembles Trinucleus and other Trilobites, a conclusion to which the whole account points. The Trilobites are therefore lower than the Xiphosura; the two groups should, on embryonic and structural grounds, be included perhaps in one order; and the former should therefore be removed from the neighbourhood of the Phyllopods and placed immediately next to Xiphosura. The organization 
and habits of Limulus throw much light on the probable anatomy and habits of Trilobites. The author infers that the eyes had a similar structure, that the circulation and the nervous system were alike, and that probably the genital organs were very similar in the two groups. He thence suggests that the eggs of the Trilobite were probably laid in the sand or mud and impregnated by the spermcells of the male floating freely in the water. The Trilobites probably lived by burrowing in the mud and sand, digging in the shallow palæozoic waters after worms and stationary soft-bodied Invertebrates.-The American Chemist, Nov. 1870.

On the Stipules of Magnolia and Liriodendron. By Thomas Meehan.

An examination of the stipules of Magnolia affords some highly interesting facts, most or perhaps all of which are known to leading botanists, but which do not appear to be as generally known as they deserve to be; and these facts may have a more intimate bearing on many of the questions connected with the laws of development than is suspected.

In most species of Magnolia a scar peculiar to the genus exists on the petiole. This scar is elevated somewhat above the surrounding tissue, as if the matter forming it had been laid on the surface after the rest of the petiole had been formed. The green is not of the same tint as in the rest of the petiole, but it is always of the same tint as that of the leaf-blade. In Magnolia macrophylla the petiole and under surface of the leaf are grey; the leaf-blade is pale green on the upper surface. The surface of the scar is pale green, corresponding to the surface of the leaf-blade. The whole appearance of the scar is such as if a portion of a leaf-blade had been grafted by its under surface on the petiole.

On the upper part of the scar next the leaf-blade are two small articulation points, where the membranaceous stipules finally parted from the leaf. Examining a leaf before these stipules have fallen, the main veins forming the skeleton of the stipules are found connecting with these articuli, and, spreading out, diverge downward toward the base of the leaf. In separating at maturity from the petiole, they part first from the base, and last from their place of articulation. Their weakest hold is the point furthest away from what thus appears to be their source at the apex of the scar.

Magnolia Frazeri elongates its petiole beyond the stipule several inches generally. The leaf-blade then exhibits the auricle so well known in this species. The structure of this auricle is similar to the stipules in M. macrophylla or M. tripetala. The veins start out in nearly as close a fascicle as in these stipules, and they diverge and curve downwards just as these stipules do. Above these strong veins of the auricle are very weak veins, necessitating a very narrow blade portion there, until another set of strong veins push out and make the main part of the lamina.

If we press these auricles back against the petiole, and imagine a 


\section{$2 \mathrm{BHL}$ Biodiversity Heritage Library}

Packard, A. S. 1871. "On the embryology of Limulus polyphemus." The Annals and magazine of natural history; zoology, botany, and geology 7, 68-69. https://doi.org/10.1080/00222937108696319.

View This Item Online: https://www.biodiversitylibrary.org/item/81026

DOI: https://doi.org/10.1080/00222937108696319

Permalink: https://www.biodiversitylibrary.org/partpdf/62585

\section{Holding Institution}

Smithsonian Libraries

\section{Sponsored by}

Smithsonian

\section{Copyright \& Reuse}

Copyright Status: Public domain. The BHL considers that this work is no longer under copyright protection.

This document was created from content at the Biodiversity Heritage Library, the world's largest open access digital library for biodiversity literature and archives. Visit BHL at https://www.biodiversitylibrary.org. 